\title{
有機アルミニウム反応剤を用いる有機合成
}

$$
\text { 中 井秀 一*・山本尚** }
$$

\section{Organic Synthesis Using Organoaluminum Reagents.}

\author{
Shuichi NAKAI ${ }^{*}$ and Hisashi YAmamoto $* *$
}

\begin{abstract}
Organoaluminum compounds are produced commercially and are accessible readily as inexpensive raw materials.

Herein, a number of applications of organoaluminum compounds in organic synthesis are reviewed (1982-1985), which includes
\end{abstract}

1) synthesis of organoaluminum compounds by hydroalumination and carboalumination, 2) aluminum hydrides,

3) alkyl aluminums, 4) alkyl aluminates, 5) hetero-substituted aluminums, 6) Tebbe reagent, 7) catalytic reaction, 8) asymmetric reaction.

\section{1.はじめに}

21 世紀における有機合成化学の最も重要な使命は, 位置および立体化学を思い通りに制御した精密かつ一般 性のある選択的合成反応体系の実現であろう。それは， 単に収率の向上をもたらすだけでなく，いかなる異性体 の分離精製をも必要としないシンプルで強力な夢の合成 プロセスの実現を可能にし，工業的にも測り知れない意 義がある。

こうした高選択的な反応の開発には有機金属化合物は 不可欠である。たしかに，周期律表にはさまざまな特徵 を備えた金属がそろっており，その性質を活用すればい かなる化学変換も思いのままになるであろう。一般的に, 典型元素は価数の変化がないので化学量論的反応に用い られ, 反応の設計が容易であるが反応の広がりが小さい。 一方，遷移金属は価数が変化するため触媒作用があり， いろいろな反応が考えられるが，反面，反応設計が難し いと言える。

典型元素のなかでも $\mathrm{Li}, \mathrm{Mg}, \mathrm{B}$ 等は有機合成の研究で日 常的に用いられていたのに反し，Al は石油化学分野で の利用が先に完成した。Alfene \& Alfol 法(スキーム1) における $\mathrm{Et}_{3} \mathrm{Al}$ や $\mathrm{PP}$ 重合における $\mathrm{Et}_{2} \mathrm{Al} \mathrm{Cl}$ 等は, 工業 的に大量に使用され, 日本国内で $4000 \mathrm{t} / \mathrm{y}$ の規模で生

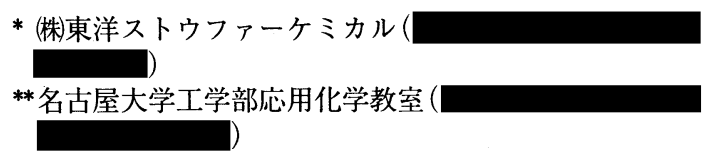

産されている。これらは価格も安く，入手し易い有機金 属化合物であるが，精密有機合成反応における利用は， 最近になってようやく盛んになりはじめた。工業的に簡 単に利用されうるので, 今後は急速な発展が期待される。

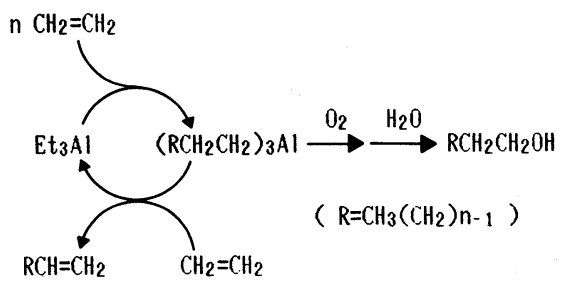

Scheme 1

有機合成反応に利用する場合の有機アルミニウム化合 物の特徴を列記する。

1）Lewis 酸性を示すこと。Al は，空の $\mathrm{p}$ 軌道を持っ ていてエーテルのような弱い塩基にも配位する。

2) $\mathrm{Al}-\mathrm{C}$ 結合がイオン的であること。電気陰性度が $\mathrm{Al}$ が 1.47, C が 2.50 であるため $\alpha$ 炭素上のアニオン性 が大きくカルボアニオンとして利用できる。

3）“Ambiphilic”な性質を持っていること。1）と2) の $\mathrm{Al}$ の Lewis 酸性と配位子の求核性を利用した $\mathrm{Al}$ 独 自の反応が設計できる。

4) アニオン性反応剤とアート錯体を形成すること。

* Toyo Stauffer Chemical Co., Ltd.

**Department of Applied Chemistry, Faculty of Engineering, Nagoya University ( $\square$ 
アート錯体は，よい求核反応剂として利用され，特にア ルケニルアルミナートは有用である。

5）Alとへテロ原子の結合は切断され易いこと。 $\mathrm{N}, \mathrm{S}, \mathrm{Se}$ 等と $\mathrm{Al}$ の結合は切れ易く, これらの基を容易に 基質に導入できる。一方, 酸素やハロゲンと $\mathrm{Al}$ の結合 は強く安定である。

これらの特徴を用いて数多くの反応が開発され，すで に成書や総説にまとめられている ${ }^{1,2)}$ 。本稿では, 1982 年以降を中心に有機アルミニウム化合物を用いた 反応をまとめた。

\section{2. 有機アルミニウム化合物の合成}

今日では, $\mathrm{Me}_{3} \mathrm{Al}, \mathrm{Et}_{3} \mathrm{Al},(\mathrm{i}-\mathrm{Bu})_{2} \mathrm{AlH}, \mathrm{Et}_{2} \mathrm{AlCl}$ 等は工 業的に生産され容易に入手することができるので，これ らの合成については省略する。ここでは，これら入手容 易な有機アルミニウムから誘導されるアルキル，アルケ ニル，アルキニルアルミニウム化合物の合成について述 ベる。

オレフィンやアルキンからアルキルまたはアルケニル アルミニウム化合物を合成するには，ヒドロアルミネー ション (以下 HA と略す)とカルボアルミネーション(以 下 CA と略す)がある。HA はアルミニウムヒドリドの 不飽和結合に対する付加反応であり，CA はアルキルア ルミニウムの不飽和結合に対する付加反応である。いず れも位置選択的に anti-Markownikov 型で，立体選択的 にシス付加である。

オレフィンに対する $\mathrm{HA}$ および CA から同一のアルキ ルアルミニウム化合物を直接合成できる。しかし，CA は反応条件が厳しく $\left(>100^{\circ} \mathrm{C}\right)$ 温和な条件で反応する HA が有用である。アルキンに対する HA または CA か らは異なったアルケニルアルミニウム化合物が直接合成 でき，HA と CA は相補的関係でいずれも有用である。

$\mathrm{HA}$ や CA で得られない有機アルミニウム化合物は, トランスメタレーションで合成できる。Alょり電気陰 性度の低い金属 ( $\mathrm{Li}, \mathrm{Na}, \mathrm{Mg}, \mathrm{Hg}$ 等)の有機金属化合物と八 ロゲン化アルミニウムの反応で有機アルミニウム化合物 を合成する。

2.1. ヒドロアルミネーション(HA) アルミニ ウムヒドリドは, 反応性や立体化学の違いからヒドロア ランと $\left(\mathrm{Cl}_{2} \mathrm{AlH},(i-\mathrm{Bu})_{2} \mathrm{AlH}\right)$ とヒドロアルミナート $\left(\mathrm{LiAlH}_{4}, \mathrm{LiAl}(i-\mathrm{Bu})_{2} \mathrm{MeH}\right)$ に分けられる。一般的にヒド ロアランはシス付加が，ヒドロアルミナートはトランス 付加が起こる。

ヒドロアランによるオレフィンの HA では, “mixed" アルキルアルミニウム $\left(\mathrm{R}_{2}^{1} \mathrm{AlR}^{2}\right)$ が生成する。この反応
は，末端オレフィンでは速く内部オレフィンでは極端に 遅くなる $(\text { 式 } 1)^{3)}$ 。

$\mathrm{CH}_{2}=\mathrm{CH}_{2} \approx \mathrm{CH}_{2}=\mathrm{CHR}>\mathrm{CH}_{2}=\mathrm{CR}_{2}>\mathrm{R}^{1} \mathrm{CH}=\mathrm{CHR}^{2}$

反応温度を高くすると，アルキル基が $\beta$ 脱離して $\alpha$ オレフィンとヒドロアランに戻る。 $\mathrm{Cp}_{2} \mathrm{ZrCl}_{2}$ を触媒と すると低温で反応が進行する (式 2$)^{4)}$ 。

$\mathrm{Al}$ が付加する位置は，オレフィンの置換基の電子的 効果と立体的効果に影響されるが，一般的に末端オレフ インでは $\beta$ 位に付加し, $\beta / \alpha$ の比は $96 / 4$ 以上と選択性 がよいが, 内部オレフィンでは選択性は全くない。生成 した“mixed”アルキルアルミニウムは, 室温でアル キル基の交換をするため純度高く得ることは困難である (式 3) ${ }^{3)}$ 。

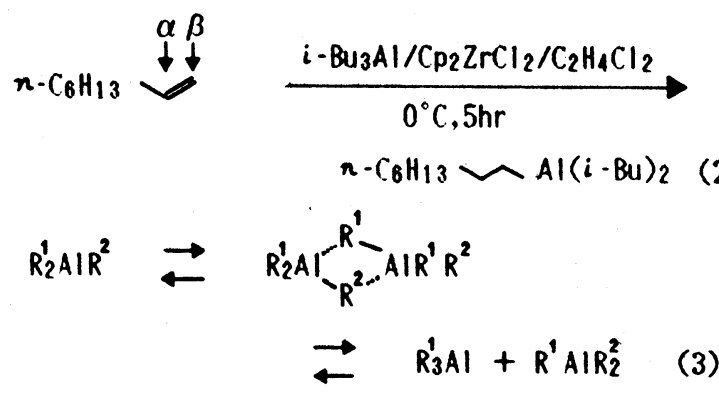

アレンや共役ジエンの HA では, アリルアルミニウム が生成するが， $\alpha / \gamma=96 / 4$ また $\alpha / \delta=60 / 40$ と Al は 内部に付加し易い(式 4,5 $)^{5,6)}$ 。この位置選択性は, $\mathrm{Cp}_{2} \mathrm{TiCl}_{2}$ を触媒として用いても変わらない7)。一方, 非共役ジエンでは, 両末端への $\mathrm{Al}$ の付加以外にしばし ば環化反応が進行し，合成的に興味あると言える ${ }^{8)}$ 。
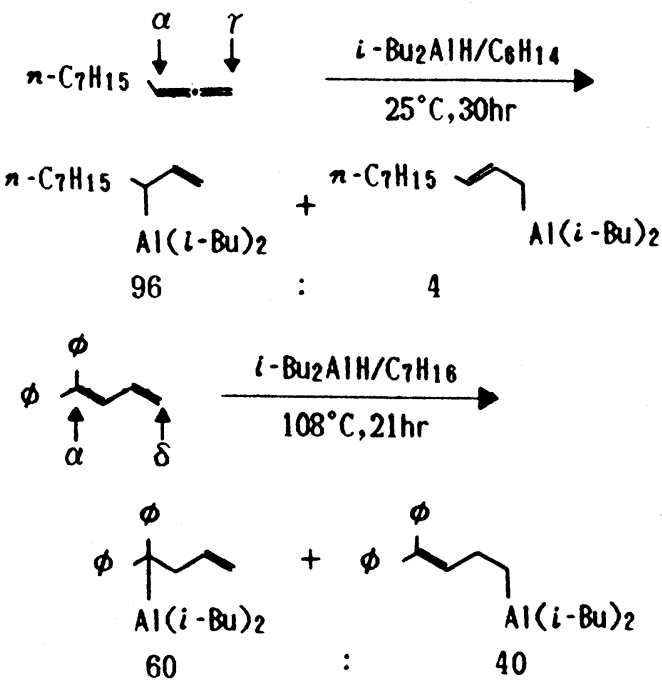

(5) 


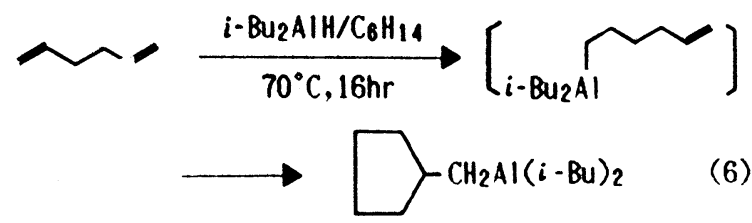

98\%

アルキンの HA で，アルケニルアルミニウム化合物が 生成する。アルケニル基はアルキル基に比べ求核性が弱 く，基質に容易に導入される。例えば，プロスタグラン ジン $\mathrm{E}_{1}$ 誘導体の合成にも利用され (式 7 $)^{9)}$, 有機合成 反応剂としての価値が高い。
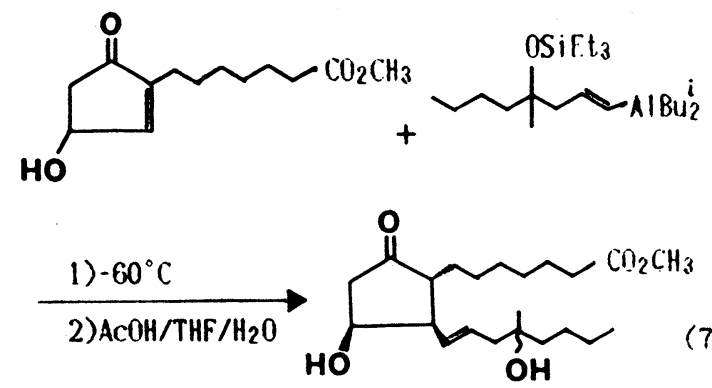

アルキンの HA は, 高温では $\beta$ 脱離や 2 量化などの副 反応が進行するため反応温度は低くする必要がある。し かし，末端アルキンでは室温でも脱プロトンしてアセチ リドになってしまう $\left(\right.$ 式 8) ${ }^{10)}$ 。

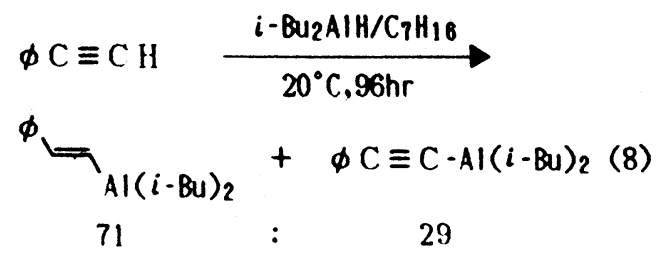

この反応は，一般的にはシス付加であるが，末端シリ ルアセチレンだけは溶媒で立体選択性を制御できる ${ }^{11)}$ 。 $\mathrm{Al}$ の付加する位置は，末端アルキンでは $\beta$ 位で選択性 も高いが内部アルキンでは選択性はみられない(表 1) ${ }^{12)}$ 。

次にヒドロアルミナートによる HA について述べる。 $\mathrm{LiAlH}_{4}$ の HA は, 触媒が存在しないと厳しい条件 $\left(110^{\circ} \mathrm{C}\right.$,加圧下) が心要であり, 通常は $\mathrm{Ti}$ または $\mathrm{Zr}$ 化 合物を触媒として温和な条件で反応が行われる。この反 応も末端オレフィンでは速く内部オレフィンでは極端に 遅くなり，この速度差を利用してジエンからアルケニル

Table 1 Hydroalumination of alkynes with $(i-\mathrm{Bu})_{2} \mathrm{AlH}$.

\begin{tabular}{|c|c|c|c|c|}
\hline $\mathrm{R}^{1} \mathrm{C} \equiv \mathrm{CR}^{2}$ & Conditions & $R_{2 A 1}^{R_{1}^{1}}=R^{R^{2}}$ & $\left.R^{R}=\right\}_{A \mid R_{2}}^{R^{2}}$ & $\underbrace{A \mid R_{2}}_{R^{2}}$ \\
\hline$n-\mathrm{C}_{6} \mathrm{H}_{13} \mathrm{C} \equiv \mathrm{CSiMe}_{3}$ & $\begin{array}{c}\text { hexane, } 25^{\circ} \mathrm{C}, 16 \mathrm{hr} \\
\text { ether/hexane, } 25^{\circ} \mathrm{C}, 20 \mathrm{hr}\end{array}$ & $\begin{array}{l}0 \\
0\end{array}$ & $\begin{array}{r}7 \\
99\end{array}$ & $\begin{array}{r}93 \\
1\end{array}$ \\
\hline$n-\mathrm{C}_{4} \mathrm{H}_{9} \mathrm{C} \equiv \mathrm{CCH}_{3}$ & hexane, $70^{\circ} \mathrm{C}$ & 33 & 73 & 0 \\
\hline$n-\mathrm{C}_{4} \mathrm{H}_{9} \mathrm{C} \equiv \mathrm{CCH}_{2} \mathrm{SiMe}_{3}$ & hexane, $70^{\circ} \mathrm{C}, 4 \mathrm{hr}$ & 42 & 56 & 2 \\
\hline 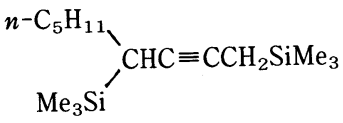 & ether, $40^{\circ} \mathrm{C}, 2 \mathrm{hr}$ & 99 & 0 & 1 \\
\hline
\end{tabular}

Table 2 Hydroalumination of olefins, dienes and alkynes with $\mathrm{LiAlH}_{4}$.

Substrate


アルミナートを合成できる。しかし，末端アルキン類で は位置選択性が悪い (表 2) ${ }^{13,14)}$ 。

アルキルリチウムと DIBAL-H のアート錯体によるア ルキンの HA では, アルケニルアルミナートが生成する。 この反応は, トランス付加が立体選択的に起こり位置選 択性もよく，有用な反応剂が合成できる(式 9) 15,16）。

$$
\mathrm{C}_{2} \mathrm{H}_{5}-\mathrm{C} \equiv \mathrm{C}-\mathrm{C}_{2} \mathrm{H}_{5} \quad \frac{\mathrm{LiAl}(\mathrm{i}-\mathrm{Bu})_{2} \mathrm{MeH} / \mathrm{diglyme}}{100-130^{\circ} \mathrm{C}, 6 \mathrm{hr}}
$$

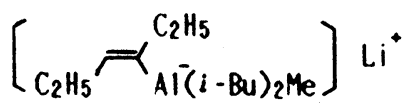

\section{$\mathrm{R}-\mathrm{C} \equiv \mathrm{C}-\mathrm{C} \equiv \mathrm{C}-\mathrm{Sime} 3$ \\ $\left(\mathrm{R}=\mathrm{R}-\mathrm{C}_{6} \mathrm{H}_{13}, t-\mathrm{BU}\right)$ \\ $\mathrm{LiAl}(i-\mathrm{Bu})_{2} \mathrm{BuH} / \mathrm{OME} / \mathrm{C}_{6} \mathrm{H}_{14}$}

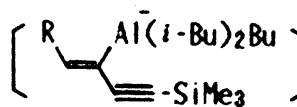

$\mathrm{Li}^{+}(9)$

2.2. カルボアルミネーション(CA) オレフィ ンの CA は，厳しい反応条件を必要とし“ mixed”アルキ ルアルミニウムが生成するため合成反応には利用されて いない(式 10) ${ }^{17)}$ 。

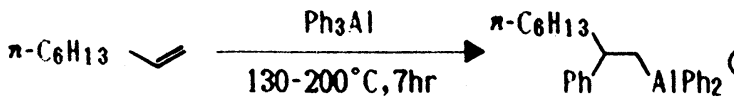

$100 \%$
アルキンの CA では，2置換または 3 置換のアルケニ ルアルミニウム化合物が生成する。触媒がないと $\beta$ 脱離, 2 量化また脱プロトンなどの副反応が起こる。 $\mathrm{Al}$ の付 加する位置は，化合物の置換基に微妙に影響され，高い 選択性が見られる場合もあるが一般性がない(表 3) ${ }^{18 \sim 20)}$ 。

一方，遷移金属触媒が存在すると反応が容易に進行し 特に, $\mathrm{Cp}_{2} \mathrm{ZrCl}_{2}$ が触媒として有用である。触媒存在下 でのアルキンの CA は， $\beta$ 脱離や脱プロトンなどの副反 応が起きず， $98 \%$ 以上がシス付加という高い立体選択 性を示す。 $\mathrm{Al}$ の付加する位置は, 主に $\beta$ 側に付加する がアルキル基によって位置選択性が異なる。トリプロピ ルアルミニウムでは，ヒドリドが生成し易いため HA 生 成物が得られるが， $\mathrm{Al}$ のルイス酸性を変えることによ

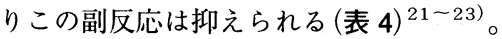

なお，この反応で- $\mathrm{OH}$ 基や-SPh 基が存在していて も位置および立体選択性には影響を及ぼさないため，官 能基を含む有機アルミニウム反応剤の合成に有効であろ う (式 11$)^{24)}$ 。

$\mathrm{C}_{6} \mathrm{H}_{13}-\mathrm{C} \equiv \mathrm{CH}$
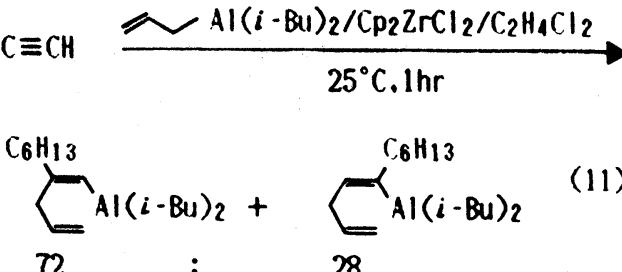

Table 3 Carboalumination of alkynes with trialkylaluminums.

\begin{tabular}{|c|c|c|c|c|}
\hline $\mathrm{R}^{1} \mathrm{C} \equiv \mathrm{CR}^{2}$ & $\mathrm{R}_{3} \mathrm{Al}$ & Conditions & $\stackrel{R^{1}}{=} \mathcal{R}_{A \mid R_{2}}^{R^{2}}$ & $\underbrace{R^{1}}_{R_{2} A 1}=K_{R}^{R^{2}}$ \\
\hline$n-\mathrm{C}_{6} \mathrm{H}_{13} \mathrm{C} \equiv \mathrm{CSiMe}_{3}$ & $\mathrm{Et}_{3} \mathrm{Al}$ & $80^{\circ} \mathrm{C}$ & 50 & 50 \\
\hline $\mathrm{PhC} \equiv \mathrm{CMe}$ & $\mathrm{Ph}_{3} \mathrm{Al}$ & $60 \rightarrow 150^{\circ} \mathrm{C}, 15 \mathrm{hr}$ & 5 & 95 \\
\hline $\mathrm{PhC} \equiv \mathrm{C}(t-\mathrm{Bu})$ & $\mathrm{Ph}_{3} \mathrm{Al}$ & $90^{\circ} \mathrm{C}, 4 \mathrm{hr}$ & 100 & 0 \\
\hline
\end{tabular}

Table 4 Carboalumination of alkynes with alkylaluminums catalyzed by $\mathrm{Cp}_{2} \mathrm{ZrCl}_{2}$.

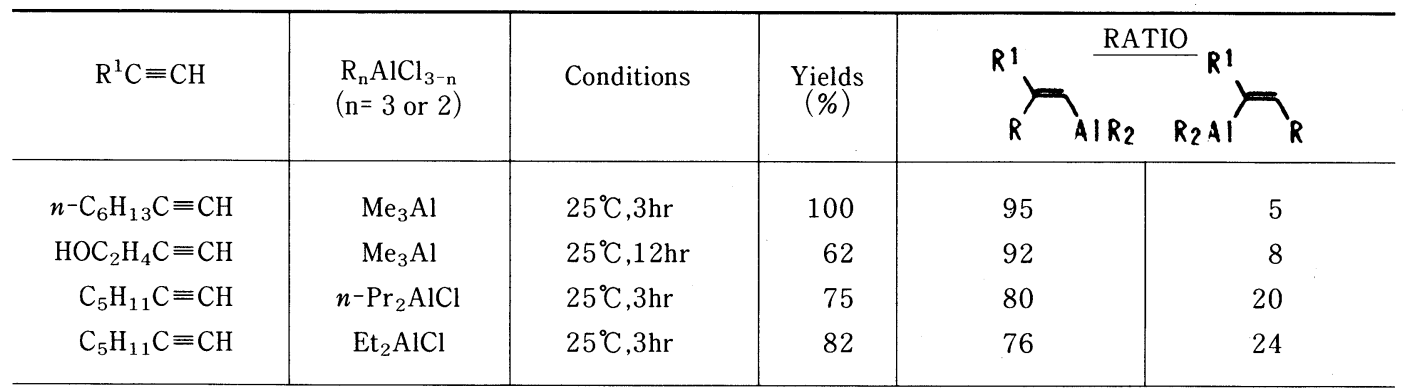


2.3. トランスメタレーション＼cjkstart有機リチウム化 合物および Grignard 反応剂と塩化アルミニウムを反応 させ，HA や CA ではできないビニルまたはアルキニル アルミニウム化合物を合成できる(式 12) ${ }^{1 \mathrm{~d} \cdot 25)}$ 。

\section{$3 \mathrm{CH}_{2}=\mathrm{CH}-\mathrm{MgX}+\mathrm{AlCl}_{3}$

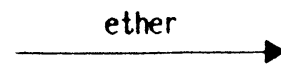$$
\left(\mathrm{CH}_{2}=\mathrm{CH}\right)_{3} \mathrm{Al} \cdot \mathrm{OEt} 2+3 \mathrm{MgClX}
$$

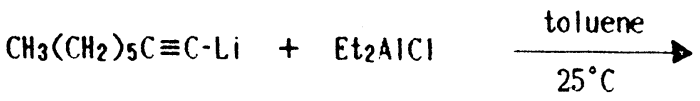

$$
\mathrm{CH}_{3}\left(\mathrm{CH}_{2}\right)_{5} \mathrm{C} \equiv \mathrm{C}-\mathrm{AlEt}_{2}+\mathrm{LiCl}
$$

\section{3. 化学量論的反応}

有機アルミニウム反応剂を化学量論量用い, 有機リチ ウム試薬や Grignard 反応剂にはないルイス酸性抢よび “ambiphilicity”の性質を生かして，基質にアルキル基， アルケニル基,ヘテロ官能基等を導入することができる。

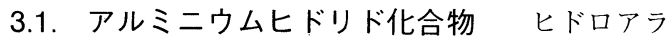
ンは, 親電子的な還元郕で Lewis 酸性の強い $\mathrm{Al}$ にカル ボニル酸素が配位し，その結果ヒドリドの求核性が高ま りヒドリドの移動が起こる。一方，ヒドロアルミナート は，求核的な還元剤でアート錯体であるためヒドリドが 高い求核性を有し，カルボニル炭素を攻撃する。一般に カルボニル基に対しては，いずれの還元凨を用いても同 一のアルコールが得られるが，基質によっては異なった 生成物を与える。

エステルを $\mathrm{LiAlH}_{4}$ で還元するとアルコールが得られ るが，DIBAL-H と低温で反応させるとアルデヒドを得 ることができる。これは，中間体のへミアセタール化合 物が安定なためと考えられる(式 13) ${ }^{26)}$ 。
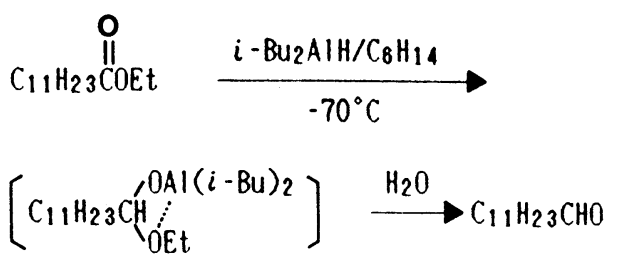

ニトリルを $\mathrm{LiAlH}_{4}$ で還元するとアミンが得られる が, DIBAL-Hではやはりアルデヒドが得られる。この 反応を巧みに利用してジニトリル化合物からピロール誘 導体を得ることができる(式 14) ${ }^{27) 。 ~}$

オキシムを $\mathrm{LiAlH}_{4}$ で還元すると 1 級アミンが主生成 物として得られるが，DIBAL-Hでは転位した2級アミ ンのみを得ることができる。一度ヒドロキシアミンに還
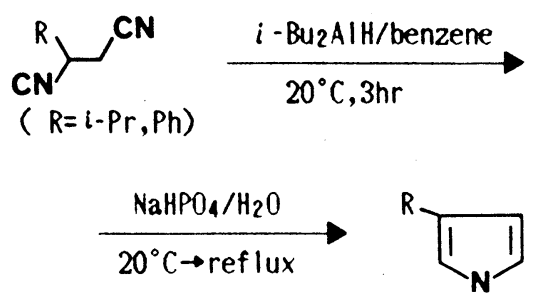

元された後転位し，また還元されたと考えられる(式 $15)^{28)}$ 。

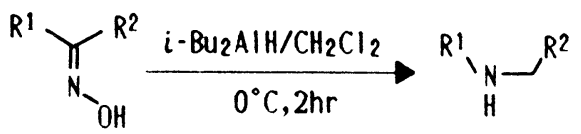

$\beta$-ラクタム化合物を $\mathrm{LiAlH}_{4}$ で還元すると環の開裂が 起こるが， $\mathrm{Cl}_{2} \mathrm{AlH}$ を用いると開環させることなく選択 的にカルボニル酸素を還元できる (式 16) ${ }^{29)}$ 。

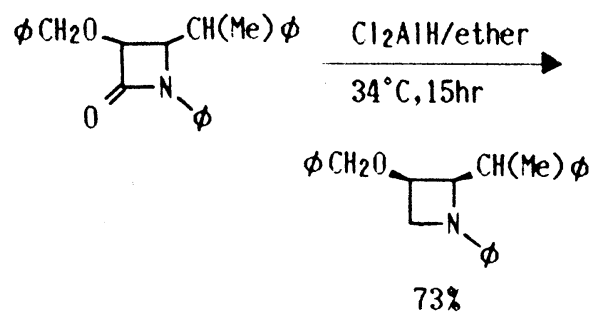

カルボン酸からアルデヒドを生成する反応は, ボラン 化合物ではあるが，アルミニウム化合物ではまだ報告は されていない(式 17) ${ }^{30)}$ 。

\section{$\mathrm{C}_{9} \mathrm{H}_{19} \mathrm{COOH}$}

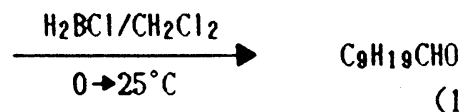

$(i-\mathrm{Bu})_{3} \mathrm{Al}$ も $\beta$ 脱離でヒドリドを放出できるため還元 剂となり得る。例えば, ジヒドロピラン化合物を用い, $\mathrm{C}-\mathrm{O}$ 切断，還元が同時に進行し4員環化合物が生成する 反応が報告されている $\left(\right.$ 式 18) ${ }^{31)}$ 。<smiles>[R]C1CCC(OCC)OC1</smiles>

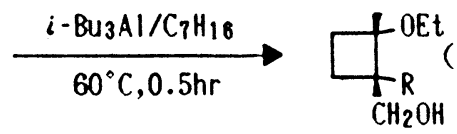

3.2. アルキルアルミニウム化合物キルア ルミニウム化合物は，無機反応剂や親電子反応剂と容易 に反応する (式 19) ${ }^{1 \mathrm{~d})}$ 。

ハロゲンと反応してハロゲン化物が得られる。特に, HA や CA で容易に生成するアルケニルアルミニウム化 合物からビニルハライド化合物が得られ，遷移金属を用 


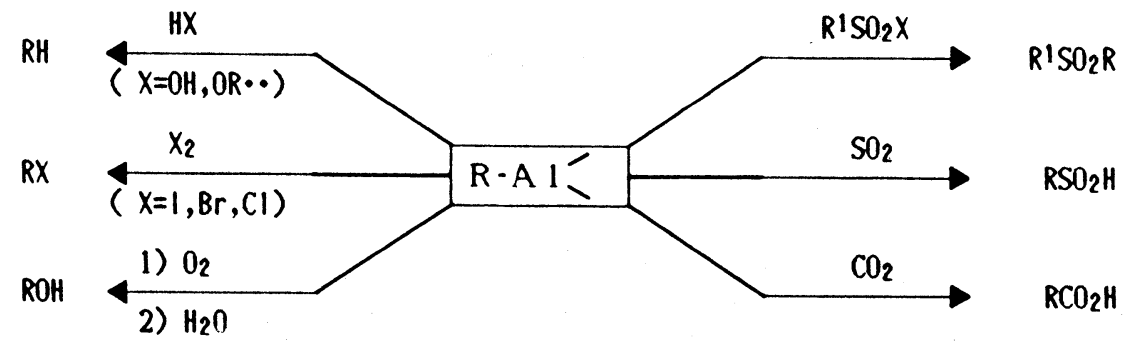

いたクロスカップリング等の有用な合成中間体となる (式 20) ${ }^{32)}$ 。<smiles>CC#CC(C)(C)CC</smiles>

THP-OCH2-C $\equiv \mathrm{C}-\mathrm{SiMe}_{3}$

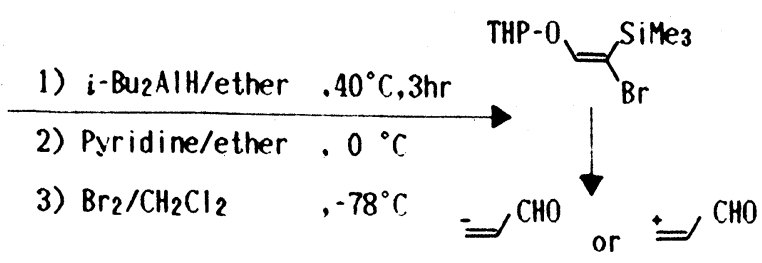

(20)

ハロゲン化物と反応してカップリングした化合物が得 られる。有機リチウムや Grignard 反応郕では，2級や 3 級のハロゲン化物の $\beta$ 脱離が起こるのに対し，アルキル アルミニウム化合物ではすみやかに反応してカップリン グ化合物が得られる(式 21) ${ }^{33)}$ 。また, 分子内にハロゲ ンがある場合には環化反応が進行する $\left(\right.$ 式22) ${ }^{34)}$ 。

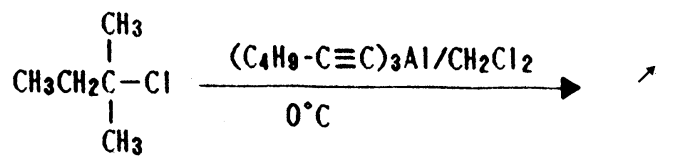

$x\left(\mathrm{CH}_{2}\right)_{2}-\mathrm{C} \equiv \mathrm{C}-\mathrm{SiMe}_{3}$

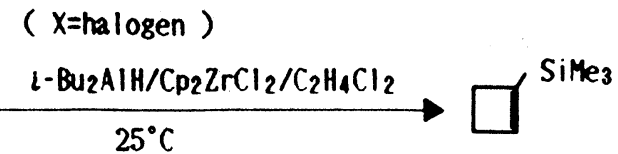

(22)

ケトンやアルデヒドのアルキル化において Grignard 反応剤やアルキルアルミニウム化合物を用いると，還元 反応も起こるため一般的には有機リチウムが有用であ る。しかし，シクロヘキサノンのアルキル化では，アル キルアルミニウムは有機リチウムや Grignard 反応剂に はない立体選択性が得られる(表 5) ${ }^{35)}$ 。例えば, $\mathrm{Me}_{3} \mathrm{Al}$ が 0.5 当量の場合は, カルボニル酸素にアルミニ ウムが配位し，四中心を経てメチル基が付加するためア キシアルアルコールが主に得られる。一方, $\mathrm{Me}_{3} \mathrm{Al}$ が2 当量の場合は過剩の $\mathrm{Me}_{3} \mathrm{Al}$ があるため 6 員環遷移状態 を経てメチル基が付加するためエクアトリアルアルコー ルが主に得られる ${ }^{1 \mathrm{a})}$ 。

$\alpha, \beta$-不飽和ケトンへ共役付加を行うには，一般的に 有機銅反応剂が用いられる。典型金属であるアルミニウ ムは硬い酸となるため 1.2 付加が優先する。しかし, 基 Table 5 Methylation of cyclohexanone.
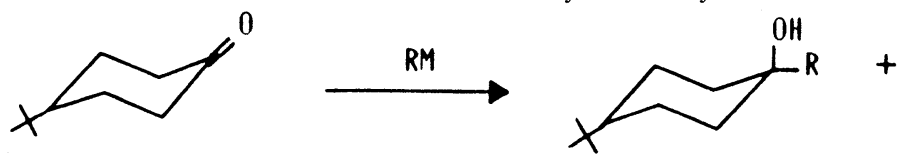

a

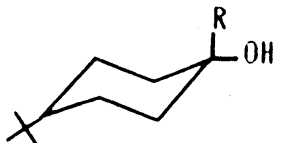

h

\begin{tabular}{l|c|c|c}
\hline \multirow{2}{*}{$\mathrm{RM}$} & \multirow{2}{*}{ Solvents } & \multicolumn{2}{|c}{ Ratio } \\
\cline { 3 - 4 } $\mathrm{MeLi}$ & ether & 65 & $\mathrm{~b}$ \\
$\mathrm{Me}{ }_{2} \mathrm{Mg}$ & ether & 62 & 35 \\
$2 \mathrm{MeMgl}+\mathrm{ZnCl}_{2}$ & ether & 38 & 38 \\
$\mathrm{Me}_{3} \mathrm{Al}(0.5 \mathrm{eq})$ & benzene & 80 & 62 \\
$\mathrm{Me}_{3} \mathrm{Al}(2 \mathrm{eq})$ & benzene & 17 & 20 \\
& & & 83 \\
\hline
\end{tabular}


質に適当な官能基があるとそれを手がかりとして共役付 加が起こる(式23) ${ }^{36)}$ 。

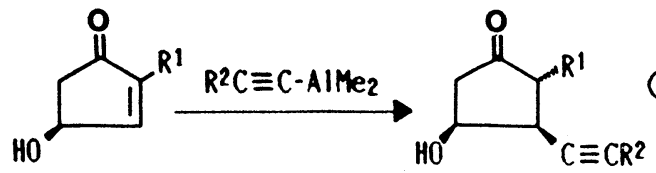

エポキシドとの反応では， Markownikov 型にアルキ ル化したアルコールが得られる(式24) ${ }^{37)}$ 。有機リチウ ムや Grignard 反応剤では, プロトンの引き抜きが起き たり，位置選択性がみられない場合が多い。位置選択性 は, アルキルアルミニウム化合物の Lewis 酸性と “ambiphilic”な性質によって発現する(式25)。
Buo $\sim 2$<smiles>CCC(CC(Br)Br)C(=O)O</smiles>

$\mathrm{CH}_{3}$

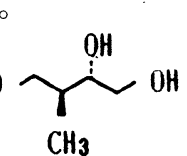

$\mathrm{CHO}$<smiles>[R]C(C)CO[Al](C)C</smiles>

(25)

オキシムと有機リチウムが反応すると $\alpha$ 位のプロトン が引き抜かれ $\alpha$ 位がアルキル化されたオキシムが得られ る (式26) ${ }^{38)}$ 。一方, アルキルアルミニウム化合物では, アルミニウムが強く酸素に配位した後転位が起こり, 求
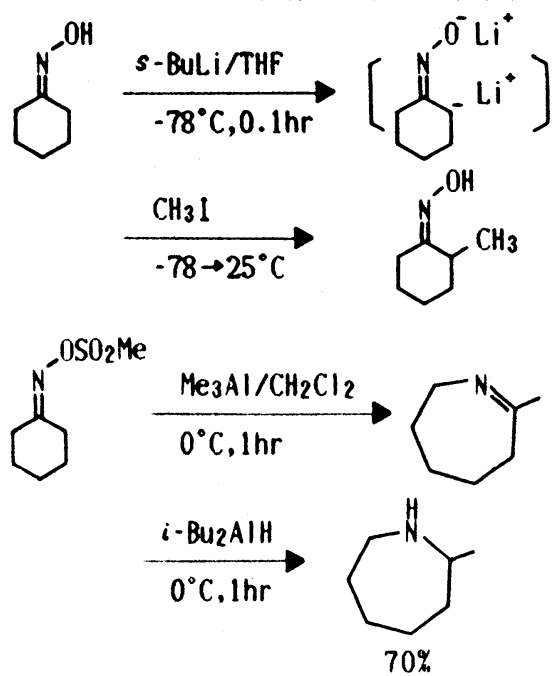

(27)
核性の高まったアルキル基が攻撃してシッフ塩基が生成 し還元後2級アミンが得られる(式27 ${ }^{39)}$ 。

アリールヒドロキシルアミンの誘導体と反応するとア リール基への求核置換反応が起こる。一般に，アリール 基への反応は Friedel-Crafts 反応の親電子反応が有名で あるが，有機アルミニウム反応剂を用いることにより求 核反応が可能となった (式 28) ${ }^{40)}$ 。

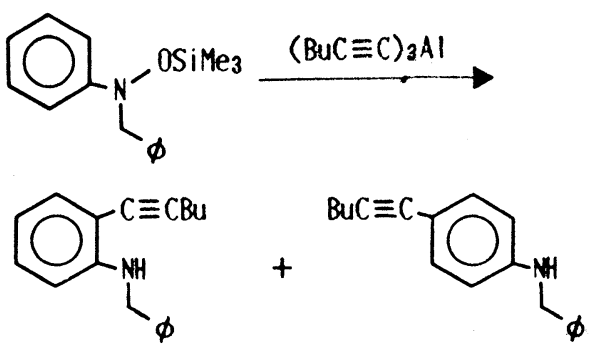

3.3. アルキルアルミナート化合物 アルキルア ルミナート化合物は，アルキルアルミニウムと有機リチ ウムにより得られる求核性の高いアート錯体である。ア ルキンから HA で容易に生成するアルケニルアルミニウ ムは求核性が弱いが，アート錯体とすると求核性が高ま り有機合成反応剂として有用となる。<smiles>COC1OC2OC(C)C3CCC(C1CCC(C)C)C23</smiles>
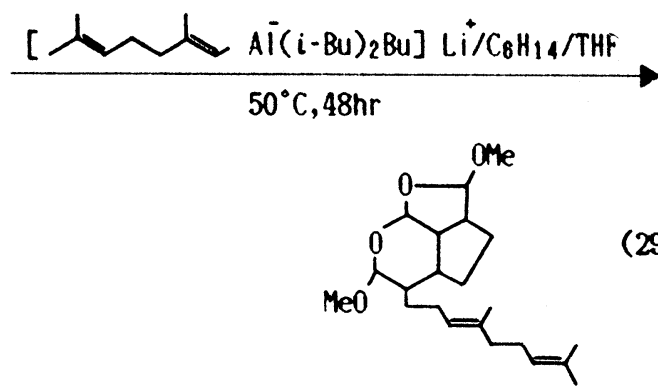

(29)

ハロゲン化物との反応は, アルキルアルミニウム化合 物が 3 級ハロゲン化物とすみやかに反応したのと異な り，1級ハロゲン化物と収率よく反応する (式 29) ${ }^{41)}$ 。

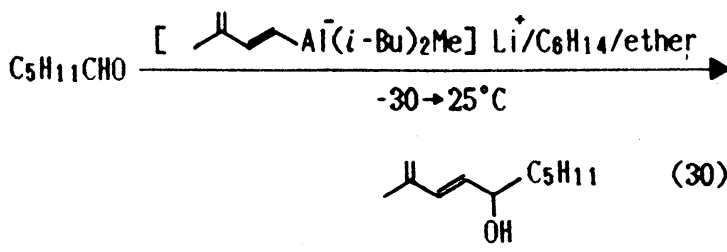


アルデヒドと反応してアルコールが得られるが，アル ケニル基の場合立体化学は保持される。一般的に，アル キルアルミニウム化合物よりも反応が進行し易く収率も 高い (式 30 $)^{42)}$ 。

$\alpha, \beta$-不飽和ケトンでは共役付加が起こる。アルキル アルミニウム化合物の場合と異なり transoid $の ~ \alpha, \beta$-不 飽和ケトンに対しても共役付加が起こり，1,2 付加が起 こらないのが特長である(式31) ${ }^{43)}$ 。<smiles>O=C(O)CCCCCCC1=CCCC1=O</smiles>
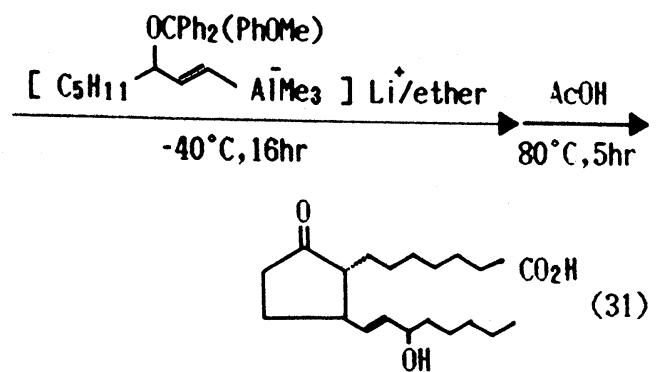

エポキシドとの反応では，立体的に混みあっていない 側より攻撃して付加した生成物が得られ，アルキルアル ミニウム化合物の場合とは位置選択性が逆になる(式 32) ${ }^{44)}$ 。しかし，シクロヘキセンオキシドのような立体 障害の大きいエポキシドとはうまく反応が進行しない。
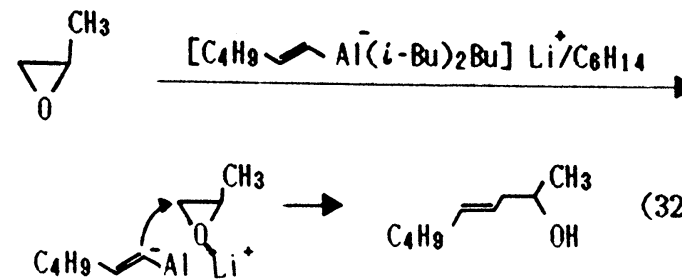

ジメチルメチルチオスルホニウムフルオロボーレート (DMTSF) のオレフィンへの求核置換反応では，得られ たスルホニウム基に対してリチウムアセチリドは中間体 のジメチルスルフィド基を脱離させるが，アルキニルア
ルミナートを用いると収率よく生成物が得られる(式 33) ${ }^{45)}$ 。

3.4. ヘテロ置換アルミニウム化合物 ヘテロ置 換 $(\mathrm{N}, \mathrm{S}, \mathrm{Se}, \mathrm{Si})$ アルミニウム化合物は， $\mathrm{Al}-\mathrm{C}$ 結合に比 べて切断され易いため基質にへテロ置換基を導入する反 応剂となる。これは，アルミニウムの空軌道で安定化さ れていたへテロ原子の非共有電子対が，アルミニウムが 基質に配位することにより不安定となり反応性が高まる ことによる。

アルミニウムアミドとエポキシドは，温和な条件で反 応し収率よくアミノアルコールを生成する (式34) ${ }^{46)}$ 。 アミンとエポキシドの反応は，加熱が必要である。

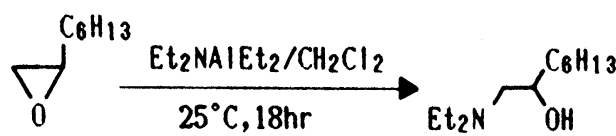

アルミニウムチオラートをオキシムと反応させると転 位の後メチルチオ基が導入されたイミノチオエーテルが 生成する(式35) ${ }^{47)}$ 。

シリルアルミニウムをアセチレンと反応させるとシリ ル基とアルミニウムが cis 付加した化合物が得られる (式36) ${ }^{48)}$ 。
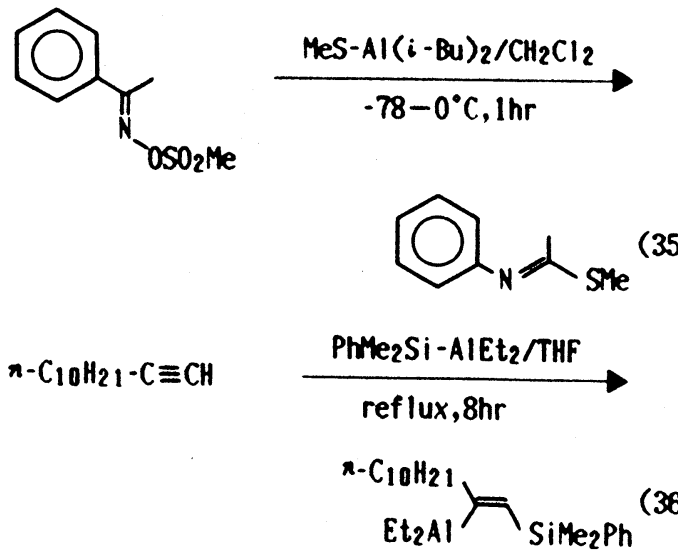

(35)

3.5. Tebbe 反応剂 オレフィン重合触媒として 有名な Ziegler-Natta 触媒と同様 Tebbe 反応剂は $\mathrm{Ti}$ と
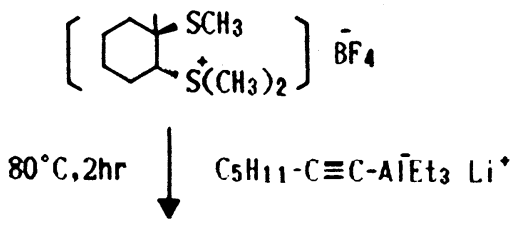<smiles>CCCCCCCC#CC1=C(C)CCCC1</smiles><smiles>C[C@@H]1CCCCC1C#C[AsH2]</smiles>

$88 \%$ 
Al を含み，Tikシクロペンタジエニドが配位している ため安定である(式37 $)^{49)}$ 。

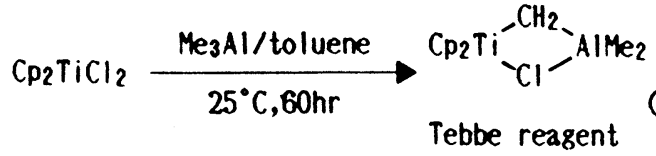

カルボニル基とはメタラサイクルを経てメチレン化反 応が進行する。特に, エステルのカルボニルをメチレン 化するにはWittig 反応剤では不可能であるが, Tebbe 反応剂により収率よく反応が進行することが見出された (式38) ${ }^{50)}$ 。また，エノール化し易い環状ケトンとも収 率よく反応が進行する $\left(\right.$ 式39) ${ }^{51)}$ 。

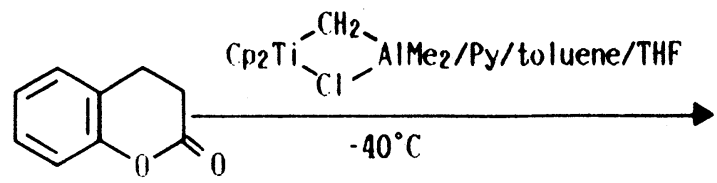<smiles>C=C1CCc2ccccc2O1</smiles>

(38)

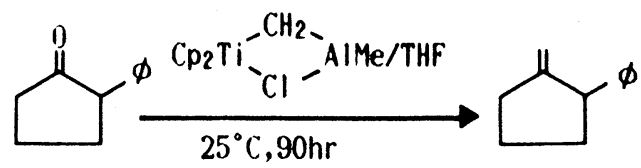

\section{4. 触媒 反応}

有機アルミニウム化合物を用いる触媒反応は，アルミ ニウムを Lewis 酸触媒とする場合とアルミニウム反応 剂と遷移金属触媒を用いる場合がある。

4.1. Lewis 酸触媒有機アルミニウム化合物の Lewis 酸性は，置換基によって自由に強さを制御できる。 ハロゲンなどの電子吸引基が結合すると強い Lewis 酸

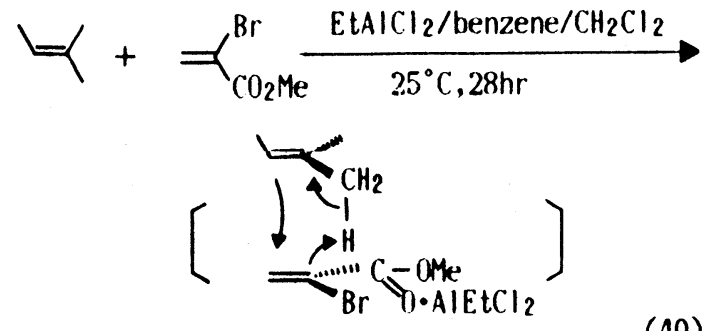

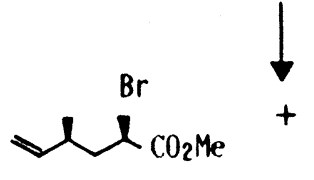

$88 \%$

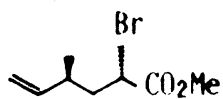

$5 \%$
となり，アルコキシ基などが結合すると弱くなる。また， 有機溶媒に溶けるので均一系で反応が行え取扱いも容易 である。

エン反応は 2 重結合に対しアリル位水素と末端の 2 重 結合が付加する反応であるが，無触媒では 200-300ㄷ の温度が必要である。触媒として $\mathrm{AlCl}_{3}$ や $\mathrm{BF}_{3} \cdot \mathrm{OEt}_{2}$ を用いると室温付近で反応するが副反応が起こるのに対 し, $\mathrm{EtAlCl}_{2}$ を触媒として用いると均一系で反応が進行 し高い收率が得られる(式 40) ${ }^{52)}$ 。

ホルムアルデヒドを用いたエン反応においては， Prins 反応が同時に起こる可能性があるが，生成する水 が $\mathrm{Me}_{2} \mathrm{AlCl}$ と反応して取り除かれるため $m$-ジオキサン 化合物は生成せず高い収率が得られる。このエン反応を 利用して 1,25-ジヒドロキシコレステロールを合成でき る。 $\mathrm{AlCl}_{3}$ 触媒では，プロトンによる2重結合の移動が 起こるためこの生成物は得られない $\left(\right.$ 式 41) ${ }^{53)}$ 。
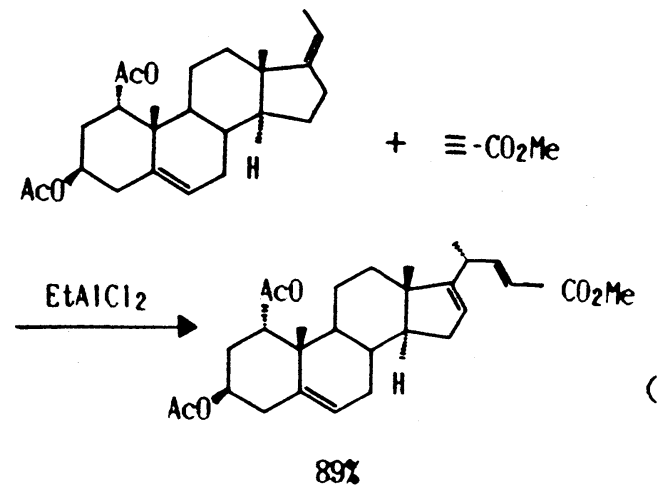

Diels-Alder 反応においても， $\mathrm{Et}_{2} \mathrm{AlCl}$ も Lewis 酸触 媒として有用である。トリエンの分子内環化反応におい て, 無触媒では $140^{\circ} \mathrm{C}$ の反応温度が必要であるが $\mathrm{Et}_{2} \mathrm{AlCl}$ を触媒とすると室温で反応が進行し高い収率が 得られる(式 42) ${ }^{54)}$ 。
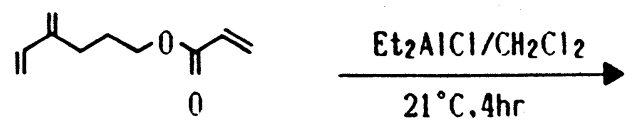<smiles>O=C(O)C1CCC=C2CCCCC2C1</smiles>

$86 \%$ (42)

アルケンと酸クロリドの Friedel-Crafts 型反応では, 当量の酸が副生し, $\mathrm{AlCl}_{3}$ 触媒を用いた場合はアルケン が異性化してしまう。しかし， $\mathrm{Et}_{2} \mathrm{AlCl}$ を触媒とすると 生成した酸が $\mathrm{Et}_{2} \mathrm{AlCl}$ と反応して取除かれるため収率が 向上する (式43) ${ }^{55)}$ 。 
$\Gamma^{1}+\mathrm{Phs} \times \mathrm{Cl}$

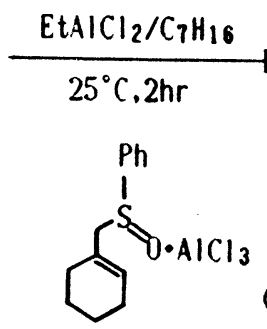

(43)

$63 \%$

シクロヘキセノンとアルケンの反応は $\mathrm{AlCl}_{3}, \mathrm{BF}_{3}$. $\mathrm{OEt}_{2}, \mathrm{TiCl}_{4}$ 等のルイス酸では起こらないが $\mathrm{Et}_{2} \mathrm{AlCl}$ を 触媒として用いると反応が進行する (式 44) ${ }^{56)}$ 。オキシ ムトシラートでは, $\mathrm{Et}_{2} \mathrm{AlCl}$ がルイス酸として作用して 転位が起こった後シリルエノールエーテルが反応して容 易に C-C 結合がつくられる(式 45) ${ }^{57)}$ 。
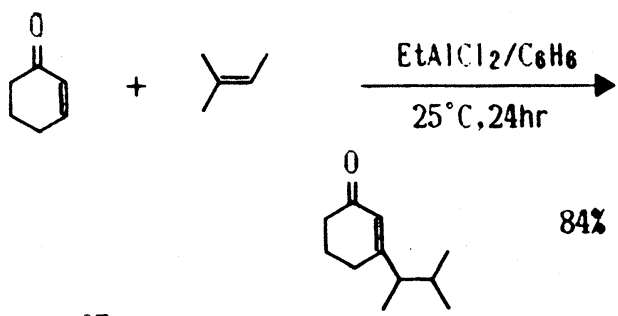

84\% (44)
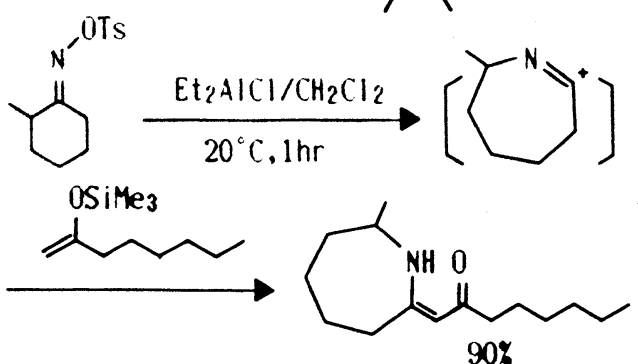

(45)

4.2. 遷移金属触媒 遷移金属触媒 ( $\mathrm{Ni}, \mathrm{Pd}$ 等) の存 在下，有機アルミニウム化合物を反応剂としてクロスカ ップリングを行うことができる。 HA P CA で得られた アルケニルアルミニウムは, 一般に求核性が低く1級八 ロゲン化物との反応は遅いが Pd 触媒を用いると収率よ くクロスカップリング反応が進行する(式 46) ${ }^{58)}$ 。アル ケニル基の導入には, 有機リチウムや Grignard 反応剤 は反応が遅くホモカップリングの副反応が起こるため合 成には用いられなかった。
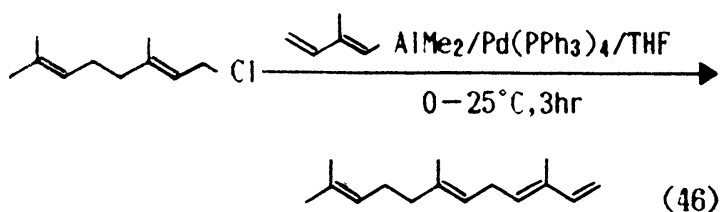

(46)

\section{5. 不斉合成反応}

天然界は高度に不斉な世界であり, 光学活性な天然物 の生理活性は多くの場合その鏡像体と著しく異なる。

一方の鏡像体のみを純粋にかつ効率よく合成する手法 (不斉合成反応) は，選択的合成反応のなかで最も困難な 分野であり 1970 代後半より活発な研究が行われ最近め ざましい成果が実りつつあり，有機アルミニウム化合物 が大活躍している分野でもある。

キラルな配位子を持つ有機アルミニウム反応剂により プロキラルなケトンをエナンチオ選択的に還元できる。 (1S) - (一) - $\beta$-ピネンを配位子としたアルミニウムクロ リドによる不斉還元が報告されている $\left(\right.$ 式47 ${ }^{59)}$ 。また, $2,2^{\prime}$-ジヒドロキシー1,1'-ビナフチルとエトキシ基を配 位子とする $\mathrm{LiAlH}_{4}$ 化合物を用いると，ほぼ完全な不斉 還元反応が起こる $(\text { 式 } 48)^{60)}$ 。
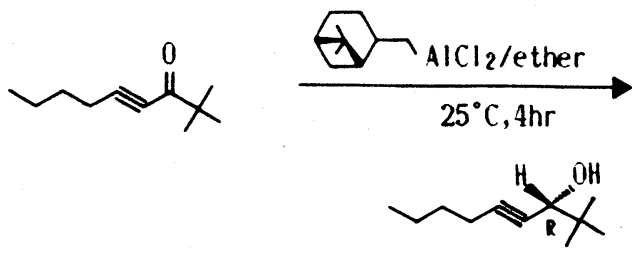

98\%, 85\%ee

$\mathrm{Ph}^{\stackrel{0}{1}}$

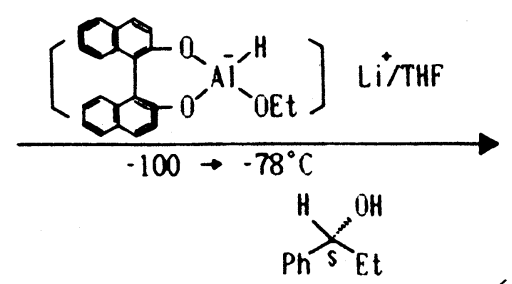

$62 \%$, 98\%ee

一方，キラルな保護基で修飾されたケトンは，ヒドロ アランによりジアステレオ選択的に還元できる。例えば， $(2 R, 4 R)-2,4$-ペンタンジオールでケトンをアセタール 化した後ヒドロアランを反応させると不斉還元的開裂が 起こり, 酸化脱離して不斉アルコールが得られる(式 49) ${ }^{61 \text { 。 }}$
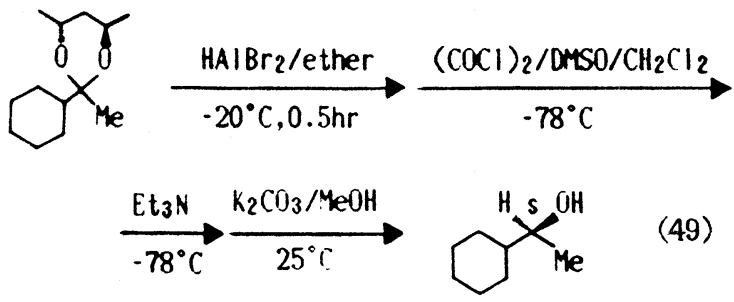
キラルな酒石酸アミドで修飾された $\alpha, \beta$-不飽和アル デヒドのアセタールにトリアルキルアルミニウムを反応 させると, キラルな $\beta$-置換アルデヒドが得られ不斉 Michael 付加と形式的には同じ結果となる (式50) ${ }^{62)}$ 。

Ph

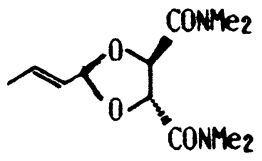

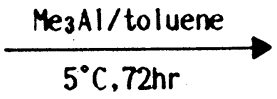

HOCONME2
$\mathrm{Ph}$<smiles></smiles><smiles>CC(CC=O)c1ccccc1</smiles>

キラルな乳酸エチルから誘導された $\alpha$-ヒドロキシメ シラートに $\mathrm{Et}_{3} \mathrm{Al}$ を作用させると, $\mathrm{MeSO}_{2}$-基の脱離に 伴ない転位が起こりキラルなケトンが生成する(式 $51)^{63)}$ 。
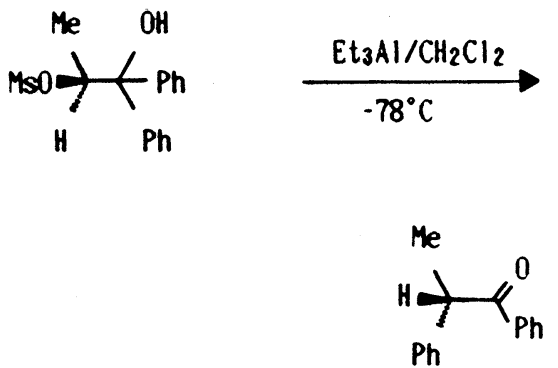

\section{3\%, 99\%ee}

キラルなヒドロキシビナフトールが結合したネロール は，脱離後環化する時に不斉が誘起されキラルなリモネ ンが生成する(式 52) ${ }^{64)}$ 。これは, キラルな脱離基とし 初めての例である。
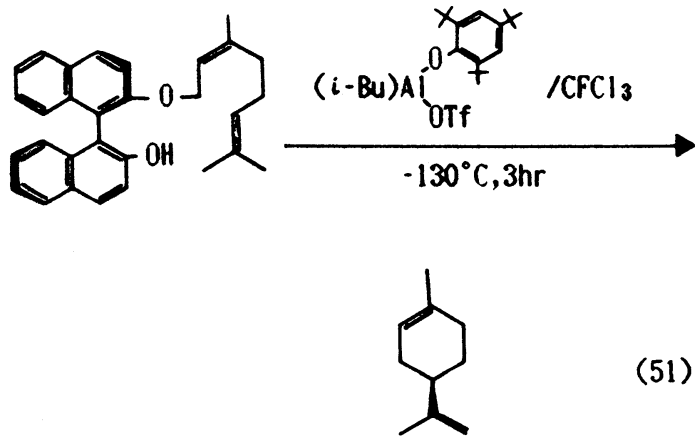

Diels-Alder 反応においても，キラルな 1,2-オキサゾ リンを不斉源とし $\mathrm{Et}_{2} \mathrm{AlCl}$ を触媒として用いると中間体 の構造が固定されるため, endo/exo比 $=100 / 0$ という高 い不斉収率が得られる(式 52) ${ }^{65)}$ 。

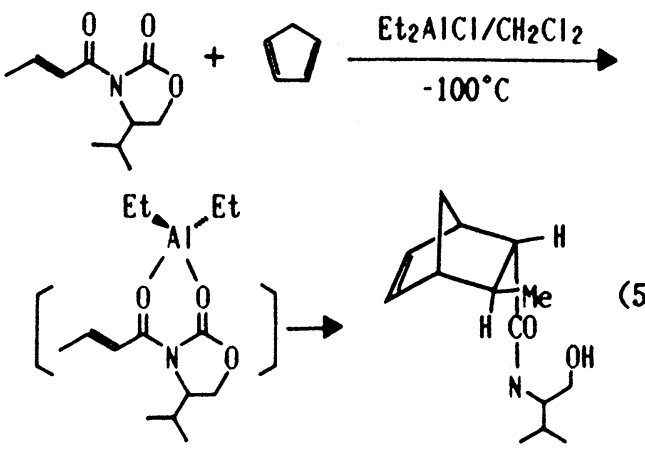

6.おわりに

本稿では，有機アルミニウム化合物をタイプ別に分類 しそれぞれの特徴が示されるようにまとめた。有機アル ミニウムの化学はまだまだこれから研究される余地が多 くあり数多くの可能性を秘めている。なお, 著者の内, 中井は有機金属メーカーの一員として研究の発展に寄与 できるように依頼されればサンプルを供給する所存で す。

（昭和61年2月 3 日受理）

\section{文献}

1a）丸岡啓二, 大䳦幸一郎, 山本 尚, 化学増刊96, “有機合成の新反応剂”, 25 （1982）

b) J. J. Eisch, "Comprehensive Organometallic Chemistry"

(G. Wilkinson ed.) Vol. 1, chap. 6, Pergamon Press, 1982

c) J. R. Zietz, G. C. Robinson, K. L. Lindsay, ibid., Vol. 7, chap. 46, Pergamon. Press, 1982

d) E. Negishi, "Organometallics in Organic Synthesis”, Vol.I, chap. 5, John Wiley\&Sons, New York (1980)

2a）野崎 一, 有合化, 40, 1006 (1982)

b) 内本喜一郎, 有合化, 41, 792 (1983)

c) 丸岡啓二, 山本 尚, 有合化，43, 429 (1985)

3) K. Ziegler, "Organometallic Chemistry" , ACS Monograph

No. 147 (H. Zeiss ed.), Reinhold, New York, 1960, p. 194-269

4) E. Negishi, T. Yoshida, Tetrahedron Lett., 21, 1501 (1980)

5) M. M. Gore, ibid., 21, 51 (1980) 
6) J. J. Eisch, G. R. Huck, J. Organomet. Chem., 4, 415 (1965)

7) E. C. Ashby, S. A. Noding, J. Org. Chem.; 44, 4364 (1979)

8) G. Hata, A. Miyake, ibid., 28, 3237 (1963)

9) P. W. Collins, E. Z. Pajani, M. S. Bruhn, C. H. Brown, J. R. Palmer, R. Pappo, Tetrahedron Lett., 1975, 4217

10) J. J. Eisch, M. W. Foxton, J. Org. Chem., 36, 3520 (1971)

11) K. Uchida, K. Uchimoto, H. Nozaki, ibid., 41, 2215 (1976)

12) S. Rajagopalan, G. Zweifel, Synthesis, 1984, 113

13）佐藤史衛, 有合化, 38, 234 (1980)

14) E. C. Ashby, S. A. Noding, J. Org. Chem., 45, 1035 (1980)

15) G. Zweifel, R. B. Steele, J. Am. Chem. Soc., 89, 5085 (1967)

16) J. A. Miller, G. Zweifel, ibid., 105, 1384 (1983)

17) J. J. Eisch, S. Y. Liu, J. Organomet. Chem., 21, 285 (1970)

18) J. J. Eisch, J. Mantre, D. A. Komar, ibid., 159, C 13 (1978)

19) J. J. Eisch, W. C. Kaska, J. Am. Chem. Soc., 88, 2976 (1966)

20) J. J. Eisch, R. Amtmann, J. Org. Chem., 37, 3410 (1972)

21) D. E. VanHorn, E. Negishi, J. Am. Chem. Soc., 100, 2252 (1978)

22) C. L. Rand, D. E. VanHorn, M. W. Moore, E. Negishi, J. Org. Chem., 46, 4093 (1981)

23) E. Negishi, Pure Appl. Chem., 53, 2333 (1981)

24) J. A. Miller, E. Negishi, Tetrahedron Lett., 25, 5863 (1984)

25) J. Fried, C. H. Lin, S. H. Ford, ibid., 1969, 1379

26) L. I. Zakharkin, M. Khorlina, ibid., 1962, 14, 619

27) J. H. Babler, K. P. Spina, ibid., 25, 1659 (1984)

28) S. Sasatani, T. Miyazaki, K. Maruoka, H. Yamamoto, ibid., 24, 4711 (1983)

29) M. Yamashita, I. Ojima, J. Am. Chem. Soc., 105, 6339 (1983)

30) H. C. Brown, J. S. Cha, B. Nazer, Y. M. Yoon, ibid., 106, 8001 (1984)

31) R. Menicagli, C. Malanga, L. Lardicci, J. Org. Chem., 47, 2288 (1982)

32) R. B. Miller, M. I. Al-Hassan, Tetrahedron Lett., 24, 2055 (1983)

33) E. Negishi, S. Baba, J. Am. Chem. Soc., 97, 7385
(1975)

34) E. Negishi, L. D. Boardman, J. M. Tour, H. Sawada, C. L. Rand, ibid., 105, 6344 (1983)

35) E. C. Ashby, Chem. Rev., 75, 521 (1975)

36) R. Pappo, P. W. Collins, Tetrahedron Lett., 1972, 2627

37) W. R. Roush, M. A. Adam, ibid., 24, 1377 (1983)

38) M. E. Jung, P. A. Blair, J. A. Lowe, ibid., 1976, 1439

39) K. Hattori, Y. Matsumura, T. Miyazaki, K. Maruoka, H. Yamamoto, J. Am. Chem. Soc., 103, 7368 (1981)

40) J. Fujiwara, Y. Fukutani, H. Sano, K. Maruoka, H. Yamamoto, ibid., 105, 7177 (1983)

41) J. K. Whitesell, M. Fischer, P. S. Jardine, J. Org. Chem., 48, 1556 (1983)

42) A. P. Kozikowski, Y. Kitagawa, Tetrahedron Lett., 23, 2087 (1982)

43) K. F. Bernady, J. F. Poletto, M. J. Weiss, ibid., 1975,765

44) E. Negishi, S. Baba, A. O. King, J. Chem. Soc., Chem. Commun., 1976, 17

45) B. M. Trost, S. J. Martin, J. Am. Chem. Soc., 106, 4263 (1984)

46) L. E. Overman, L. A. Flippin, Tetrahedron Lett., 22, 195 (1981)

47) K. Maruoka, T. Miyazaki, M. Ando, Y. Matsumura, S. Sakane, K. Hattori, H. Yamamoto, J. Am. Chem. Soc., 105, 2831 (1983)

48) H. Hayami, M. Sato, S. Kanemoto, Y. Morizawa, K. Oshima, H. Nozaki, ibid., 105, 4491 (1983)

49) F. N. Tebbe, G. W. Parshall, G. S. Reddy, ibid., 100, 3611 (1978)

50) S. H. Pine, R. Zahlen, D. A. Evans, R. H. Grubbs, ibid., 102, 3270 (1980)

51) L. Clawson, S. L. Buchwald, R. H. Grubbs, Tetrahedron Lett., 25, 5733 (1984)

52) J. V. Duncia, P. T. Lansbury, T. Miller, B. B. Snider, J. Am. Chem. Soc., 104, 1930 (1982)

53) A. D. Batcho, D. E. Berger, M. R. Uskokovic, B. B. Snider, ibid., 103, 1293 (1981)

54) K. J. Shea, J. W. Gilman, Tetrahedron Lett., 24, 657 (1983)

55) B. B. Snider, J. Org. Chem., 46, 3155 (1981)

56) B. B. Snider, D. J. Rodini, J. W. Van Strater, J. Am. Chem. Soc., 102, 5872 (1980)

57) Y. Matsumura, J. Fujiwara, K. Maruoka, H. Yamamoto, ibid., 105, 6312 (1983) 
58) H. Matsushita; E. Negishi, ibid., 103, 2882 (1981)

59) G. Giacomelli, L. Lardicci, F. Palla, J. Org. Chem., 49, 310 (1984)

60) R. Noyori, I. Tomino, Y. Tanimoto, J. Am. Chem. Soc., 101, 3129 (1979)

61) A. Mori, J. Fujiwara, K. Maruoka, H. Yamamoto, Tetrahedron Lett., 24, 4581 (1983)

62) J. Fujiwara, Y. Fukutani, M. Hasegawa, K.
Maruoka, H. Yamamoto, J. Am. Chem. Soc., 106, 5004 (1984)

63) K. Suzuki, E. Katayama, G. Tsuchihashi, Tetrahedron Lett., 24, 4997 (1983)

64) S. Sakane, J. Fujiwara, K. Maruoka, H. Yamamoto, J. Am. Chem. Soc., 105, 6154 (1983)

65) D. A. Evans, K. T. Chapman, J. Bisaha, ibid., 106, 4261 (1984)

\section{次号予 定}

巻 頭 言

これからのスペシャリティケミカルズ

川口武夫

座 談 会

日本の合成化学発展の源流をたずねて（探る）

小田良平

津 田恭介

野 副 鉄 男

松井正直

\section{総説および総合論文}

キノノイド構造を有する拡張環状交差共役系の化学………………………………………………高＼cjkstart橋かず子

$\beta$-アシルアクリル酸構造をもつ天然物の合成………………………………………………浅 岡 守 夫

有機銅-Lewis 酸複合反応剤. 過去そして現在……………………………………………..... 本 嘉 則

高歪み飽和多環状化合物の反応一一最近の話題………………………………………………... 口 良 平

自己会合により誘導される不斉識別法とその展開…………………………………………原 昭 委

新しい試薬

トリフルオロメチル化剤 TNS-Tf 試薬…………………………………………………....梅 本 照 雄

ケミカルス覚え書き

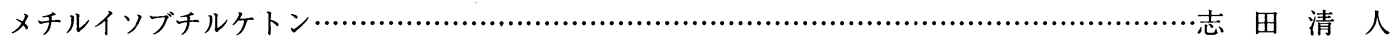

+ 字 路

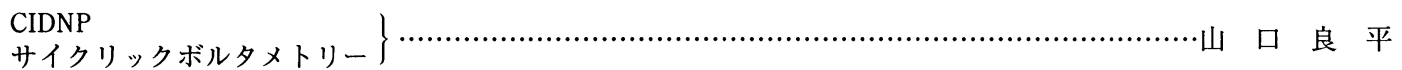

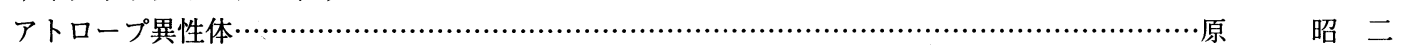

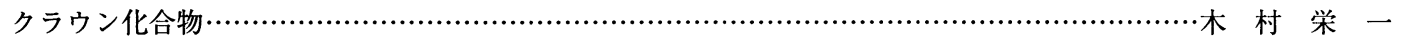

REVINDEX，新しい合成，ほか 